\title{
Equilibrium
}

Quarterly Journal of Economics and Economic Policy

VOLUME 8 ISSUE 1, 2013

ISSN 1689-765X

Jarosław Kundera*

\section{Euro Crisis and the EMU Institutional Reforms}

\section{JEL Classification: $E 42, E 58$}

Keywords: crisis, EMU, institutions

\begin{abstract}
The main goal of this article is to find the answer for the question about the necessary reform to be undertaken in the EU to save the euro as a common currency. The author envisages three scenarios of the euro area's future development. In his opinion, the most probable one are the institutional reforms in the euro area. The essential element of the reform is to establish a proper mix between the ECB' monetary policy and fiscal policies in the member states. All proposed steps against the euro crisis are mutually correlated: monetary integration requires stricter fiscal integration, fiscal integration requires banking union, but banking union is going to require some form of a political union. This way the debt crisis in the euro area may present an opportunity to renew the strength of the European institutions.
\end{abstract}

\section{Introduction}

The European Monetary Union (EMU) is a subject to a challenge by the present economic crises despite of single market success. J. Delors's report titled: 'One market, one money' analysed the benefits and costs of monetary union in the view of markets integration. The report asserted that the European Single Market needed one currency, the adoption of which would bring about further benefits from economic integration. The EU had created Euro-

(C) Copyright Polish Economic Society Branch in Toruń

Date of Submission: November 12, 2012; date of acceptance: February 27, 2013

* Contact: kun@prawo.uni.wroc.pl, Uniwersytet Wrocławski, Zakład Międzynarodowych Stosunków Ekonomicznych, budynek A, ul. Uniwersytecka 22/26, 50-137 Wrocław, Poland 
pean Single Market, and the next logical step was to establish a common currency. In Europe, like in the US, one market would be better served by one money. Against the free float, the EMU was expected to yield more opportunities to develop international transactions. The report proved that the costs of transition to a single currency were connected with early adjustment, while the benefits would arise at the end of transition, but today crisis shows that the cost and benefits were not fully evaluated. To save the euro in the long run reforms of the EMU are required

The main goal of this article is to analyse the possible scenario of European Monetary Integration (EMU) future evolution. The author tries to answer the questions what necessary reforms should be undertaken to get out from the present EMU' crisis to save the euro as common money of the EU partner countries.

\section{The Mechanism of Euro Area}

The theory of economic integration assumes that the European Monetary Integration is needed to safeguard the benefits of the internal market. The euro fostered a period of moderate inflation and greater economic integration in the single market. The euro enables partner countries to avoid transaction costs, risk of rate of exchange and large price discrepancies. All of these served development of trade and factor of production between partner countries. The euro rapidly gained international status, having become a second reserve currency in the world. The alternative to the EMU might be floating exchange rates with frequent realignments that would lead to competitive devaluations and new trade barriers. Both systems: a common currency and floating exchange rates have their benefits and costs. Monetary integration has implications for business transactions, as well as for partner countries economic policy. A country that joins the euro area will no longer be able to carry out an independent monetary policy. The growing interdependence of national economies reduces the effectiveness of member states economic policies. The unification of monetary policy implies especially coordination of fiscal policy. Each coordination and unification is connected with new institutional arrangements, economic benefits and some costs.

Many economists argue that the EU mechanism is not correctly prepared to fight against crisis. Asymmetrical shocks and reallocation of production from one region to the other happen not only in the EU, but also in the federal states, like the USA. However, in the EU, asymmetrical shocks may be more intensive and frequent. The economic diversity between European regions is much higher in the EU and the euro area than in the US (Kundera 2004, pp. 250-253). After a member state relinquishes its autonomy over 
monetary policy, fiscal adjustment becomes a key stabilizing instrument for partners in a monetary union. In the federal state there are automatic stabilizers, which transfer income from regions with growing production and tax income to regions with dropping production and income. If one of the states in the US, for example California, defaulted the federally insured financial system, it would continue to pay social security and health benefits. In the US, fiscal federalism plays a very important role in offsetting region specific shocks and is able to absorb around $40 \%$ of them: a loss of 1 dollar to the income of a US region decreases federal taxes by 34 cents and increases at the same time federal transfer by 6 cent. However, default of one of the EU member country would create much more trouble for the entire union, as it lacks the mechanism of federal states. There is no automatic mechanism of transferring Community resources into national budgets. The EU delegates the task of fighting against economic downturns to national budgets, which may be overburdened by deficits and huge national debt. There are no mechanisms of automatic stabilizers similar to that of the federal state. The EU lacks the competency to levy direct taxes and payments unemployment benefits. The relative size of common budget is too small in comparison with the national budget to have any significant macroeconomic role. While the EU budget collects about $1 \%$ of GDP of all member states, the relation of national budgets towards GDP is more than $40 \%$. A shock of one euro in regional GDP of a partner country reduces tax payments to the EU budget by only half a cent, and transfer to the common budget is able to compensate for no more than $1 \%$ of income. The main positions in the EU budget spending: Structural Funds and Common Agricultural Policy cannot act as automatic stabilizers. The aim of Structural Funds aim is to reduce the disparities between the levels of development of the various regions and the backwardness of the least favoured regions. The aids are allocated on the basis of long term programming periods (now seven years), which are difficult to change. They may only minimally and accidently alleviate the asymmetric shocks in the members states. The Structural Funds act sometimes procyclically due to the cofinance by national resources. They may also generate, as they have done in many Polish voivodeship deficit in public finances. As Structural Funds do not act as automatic stabilizers, it seems that monetary union should not include too many regions of Objective 1 more exposed to economic crises before reaching certain level of competitiveness. In order to carry out the functions of automatic stabilizers, the UE budget should have much more resources at its disposition. The hardest hit regions that surpassed the level of 75\% (like some Greek, Portugal and Spanish regions) are those where structural aids are limited or have ended. Instead of through EU aids, the growth in these regions was financed by national and regional budget deficit and accumulation of public debts. In general, it seems that federal government 
has better automatic mechanism to fight against asymmetric shocks than the EU does, where member countries concentrate their domestic insurance mechanism on their national budgets, limited additionally by Maastricht criteria and Pact of Stability and Growth.

The lack of automatic stabilizers at the EU level speaks for the autonomy and elasticity of fiscal policy at the national level. The report of 'One money, one market' emphasized: 'the stabilization role of fiscal policy at the national level is bound to remain important in the EMU as long asymmetries persist'. Fiscal autonomy is warranted and its role as an adjustment instrument arises from the need to achieve external equilibrium (European Commission 1990, pp. 100-106). However, the effects of reaction of fiscal policy and national budgets to cyclical fluctuation may be limited (it depends on its elasticity to changes in output) and relies on solidarity with partners transferring external aids during a deep recession. Studies show that the impact of automatic stabilizers is greater at the national level: the size of the public sector, tax system progressiveness and unemployment benefits, sensitivity of unemployment to cyclical fluctuation, and the share of the tax base to economic cycle are greater at the national level.

Transferring to ECB competences regarding the emission of national currency is connected also with the lost of seigniorage revenue. Seigniorage (also called the inflation tax) is the well known governmental practice connected with the ability to finance its expenditures by printing money. Such a financing of budget deficit through the issuance of low interest debt was in the past the main cause of major inflationary crisis. A tax system is rarely neutral with respect to inflation, and higher taxation follows usually higher inflation. According to the theory of optimal public finance, if the marginal cost of rising revenue by increasing taxes exceeds the marginal cost of raising it by seigniorage, the optimal policy is to reduce taxes and to increase inflation (De Grauwe 1997, p. 18). Seigniorage was an important source of government revenues for some Mediterranean countries suffering high inflation before joining the euro area (above 1\% of GDP in Italy and Spain, more than $2 \%$ of GDP in Portugal and Greece, which had inflation rate of about $10 \%$ in Portugal and $15 \%$ in Greece.

The loss of the exchange rate mechanism may bring about a balance of payment disequilibrium among partner countries of monetary union. After ten years of functioning of the euro area, two groups of member countries appeared: those with trade surplus (Germany, Holland, Austria, Belgium) and those with trade deficit (France, Italy, Spain, Portugal, Greece). In 2011, the balance of payments in relations to GDP for those countries was as follows: Germany $+4.6 \%$, the Netherlands $+6.8 \%$, Austria $+3.5 \%$, Belgium $+2.0 \%$ and in France $-3.4 \%$, Italy $-2.4 \%$, Spain $-3.8 \%$, Portugal $-8 \%$. In Ireland the balance of payment was negative in $2010-1.1$ and positive in 
$2011+1.5$. The countries with a positive balance of payments represented $39 \%$ of all the euro area population and $44.9 \%$ of the euro area GDP, while the countries with a trade deficit represented $61 \%$ of the euro area population and $55.1 \%$ of the euro area GDP. The different tendency of productivity and wages growth caused some kind of distortion in the competitiveness among member states. In 1999-2007, the wages grew by on average $14 \%$ in the euro area, while in Germany wages grew by only $2 \%$, by $17 \%$ in France, by $23 \%$ in Italy and by $26 \%$ in Spain. The difference in the cost of production contributed to the expansion of German industry on the European Single Market and the growth of its trade surplus, because Germany used strategy of wage restraint to combat the stagnation of the economy. On the other hand, France lost its competitive position in relation with Germany and became more deindustrialized economy, in which only $12 \%$ of GDP was produced in industry sector (Saint-Etienne 2011, pp. 34, 59).

So far the experiences of the euro area show that it is not asymmetrical shocks that matter the most, but rather differences in competitiveness, wages and productivity growth between members countries. Long term growth differences result in external imbalances among member countries and raise the question of whether monetary union can withstand national differences in productivity growth. A monetary equilibrium element can be achieved in the euro area in the process of long term convergence. A new threshold indicator of $3 \%$ is proposed as being acceptable to be enforced by a fine to 0.1 of GDP, but it seems that it would be difficult to execute in converging partners with strong investment needs (European Commission 2010, pp. 4-7). The necessary element of this convergence processes is that the real wages in less developed member states increase less than productivity growth could allow. However, Greece, Spain and Portugal experienced a substantial acceleration of real wage growth after entering the monetary union.

In order to finance external and internal deficit the European System of Central Bank (ESCB) has the central position in the member states of the euro area. The ESCB uses the short-term interest rates to conduct monetary policy. Like other central banks, the ECB has monopoly on the supply of cash and control over short term rates. It should be noted that in the euro area system, the common currency in circulation is just 9 per cent of broad money (M3). The ESCB finance flows via credits by the euro real - time settlement system, countries with external trade deficit receive financing from abroad, from the ECB and central banks of partners countries. There are debtor central banks in Ireland, Greece, Portugal and Spain, and creditor central banks in such countries as Germany, Luxemburg, the Netherlands, Finland, and Austria. The central banks of the debtor countries act also as the lender of last resort to country's commercial banks and lend against discounted public debt. Because of the internal payments disequilibrium huge 
assets and liability have been transferred among the national central banks with the Bundesbank as the dominant creditor. Nevertheless, when the European Central Bank financed commercial and investment banks in the form of 'quantitative easing' with loans at a low $0.75 \%$ interest rate, it could act also in favour of financing potentially solvent partners and keeping calm on the financial markets. The ECB implements quantitative easing by purchasing financial assets from banks with newly created money that increases their excess reserves. These reserves can be used to credit real economy, as well as to buy bonds. Slightly higher inflation, and a depreciation of the euro would be the cost of higher growth and debt reduction and a better way to overcome crises than the deflationary policies of highly indebted partners. However, in this system, the ECB is not acting as efficiently as, for example, the Bank of England - lender of last resort in its own banking system. There no guarantee that the ECB's 'quantitative easing would produce, even in an indirect way, a lower debt in highly indebted countries. Consequently, the market view of the UK is less sceptical despite a higher debt than in the euro area. The northern partners of the EU are reluctant to use the ECB as the lender of last resort and argue for austerity plans in highly indebted countries. Especially Germany worries that if the ECB buys governments' bonds, it will eventually be the cause of inflation. On 21 December 2011, the ECB provided 489 billion low cost three year credits to European banks known as long- term refinancing operation, and later in February 2012 additional 500 billion. The total assets of ECB increased to 3.02 trillion euro - about $1 / 3$ of the GDP of the euro area member countries. The ECB credits were seen as a kind of backdoor way of supporting government fiscal policy and debt servicing. Some European authorities had hoped that the banks would use the funds to buy high- yielding governed bonds, but they are not very willing to invest liquidity in bonds and come back partly to ECB account (New York Times 2012, p. 3). This backdoor way of financing debtor countries by ESCB cannot of course continue for very long. In the long run the only way for the debtor countries to go out from crisis is to support equilibrating of the external balance and to return to the situation, where the private sectors finance both bank and the governments.

\section{Reform of the Euro Area System}

The interest payments for some countries constituted such an important part of GDP that it might be very difficult to pay them back. The high interest rates in the euro area might come also from the competition between European bonds and American bonds. The chairman of the Vatican bank IOR shared the opinion that the United States was behind the sovereign debt cri- 
sis in the euro area. When the euro area tried to privatize the public debt, the US increased public debt to the markets from 60\% of the GDP to almost $100 \%$ of the GDP, the same markets that before had bought public debt from other countries. This led to the replacement of a good part of the euro area partners' public debt by less risky American debts. Hence, the result are portfolios with more American bonds and fewer European bonds that have to offer higher rates to be sold. In order to resolve the debt problems in the euro area and to save the monetary union from the future debts crisis, necessary steps must be taken towards not only enforcement of the Maastricht criteria, but also towards creating an effective financial aids mechanism. There are three methods to lower interest rates on bonds issues by some countries in short time:

- direct bonds purchases through the ECB;

- Eurobonds;

- financial aids.

A country experiencing a budget deficit due to servicing a high interest on bonds would have great leverage on the partner countries and their strong financial integration may speak for bailing out defaulting governments. Hence the present crisis demonstrated to the EU member countries the need to accumulate the common resources for emergency transfers to partner countries with debts and balance of payments problems. As an effect of the financial crisis the European Financial Stability Facility (EFSF) has been set up in the EU to provide temporary financial assistance to member states. The 440 billion euro participation of the euro area members was a part of a wider safety program with the IMF that was worth up to 750 billion. The amount of sovereign bonds that need to be issued to service public debt in the euro area is estimated to reach 794 billion euro in 2012 (Financial Times 2012, p. 25).

The EFSF becomes a kind of regional Monetary Fund; as such it has gained new powers: to make short term loans, to provide funds to recapitalize banks and in exceptional circumstances even buy back the governments debts (Le Figaro 2011). The access to EFSF aids is tied to strict conditionality of a rigid austerity program and budget control. However, taking into consideration the potential for really large-scale lending, the capital accumulated in the EFSF seems to be too small for the tasks. The EFSF must have the disposition fund which if necessary lends members states sufficient sum of money to avoid market borrowing at the high rates. The mechanism of financial stability acts to extend loans, for bank recapitalization and for buying bonds in the primary and secondary market. The member states unable to sell bonds at acceptable markets rates may apply for buying them by EFSF. Without bail-out funds equipped in important capital, even such fundamentally solvent countries as Italy and Spain could be forced into a debt crises. 
The mechanism of European Financial Stability Facility seemed to be only a little substitute of European Monetary Fund: as a temporary emergency facility it is going to be closed down in June 2013 (European Commission 2010b, pp. 18-199). From 2013 onwards it will be replaced the European Stability Mechanism (ESM). It seems that in the long term the EU ought to establish some kind of European Monetary Found, that would be the cornerstone of the measure formulated to deal with budgetary and euro crises in the EU.

The idea of the European Monetary Fund is not new: after the first oil shock the Community introduced borrowing and lending facilities for balance-of-payments support. The first loan for member countries whose balance of payments had been upset was granted in 1976. The Council increased the volume of borrowing to 16 billion ecu and by 31 December 2000 all borrowing was repaid (European Union Public Finance 2008, p. 362). From 1979 to 1991, the European Monetary Cooperation Fund (EMCF) existed in the framework of the European Monetary System to make intervention necessary to defend currencies in the system. The European Monetary Cooperation Fund accumulated $20 \%$ of reserves of member states to enable countries with weak currencies to borrow in order to avoid devaluation behind fixed brand and long term credits to finance structural reforms. It seems that to be effective the EFSF must follow the example of the European Monetary Cooperation Fund and establish for itself a similar function in providing the member countries with short term and long term credit. The European Monetary Cooperation Fund acted in an efficient way to support the ecu and to stabilize the money taking part in the ecu system by market intervention. The mechanism of the European Monetary System comprises three categories of aids:

- very short term facilities (from one to two months to fight with negative effects of speculative capital flows);

- short term support (from three to six months) to cope with balance of payments difficulties;

- medium term loans (from six months to several years) to ease the restructuring of the economy (Yvars 1997, pp. 310-311).

The proposed types of loans of the EFSF have accumulated less capital than the EMCF and lack of a component that is devoted to restructuring of the economy. The loans are subject to rather strict conditions and do not act in such an automatic way as in the European Monetary System.

The limited effects of intervention of the EFSF on financial market speak for application the other methods to resolve the euro area crisis: the ECB intervention, banking and fiscal union among partners with issuing the common bonds. With regard to possibilities of negative spillover in the euro area the ECB is meeting the pressure to ease monetary policy. The ECB 
intervention may have led to stabilization in financial market, but it seems that to stabilize it permanently, the level of intervention ought to be much higher. It may also not only lie on the strategy of 'quantitative easing', but it also must allow 'qualitative easing' to change the assets kept by central banks. Monetary stability in the euro area may be threatened if in one or more member states the budgetary situation could lead to default. Default in one member country could have spillover effects and negative impacts on the other member states ability to pay their, debts as well as threaten the part of banking sector in the euro area that keeps the public debts of defaulting country. In connection with a difficult situation in the banking sector, the European Commission proposed a banking union among partner countries that would create a common banking supervision and guarantee deposit throughout the euro area. To this goal a common rescue fund is envisaged to directly recapitalise banks. The banking union would force discipline on financial sector by passing rules saying that banks must give reserve for the bonds of states with large deficit. The simple way to resolve the debt problems would be, of course, the possibility to bail out the debtor country debt with ECB money. However, the Maastricht Treaty forbids the ECB to buy bonds on the primary market. While the US Federal Reserve System or Bank of England can function as the lender of last resort, the ECB cannot. Some countries ruled out relying on this intervention on primary markets, arguing that it would increase inflation rates and weaken the determination of indebted partners to restrict budget deficit and public debt.

The ECB President Mario Dragi announced the plan called: 'Outright Monetary Transaction that means a quantum shifts in the ECB activities against crisis. The ECB will wade in alongside the rescue funds purchasing bonds in unlimited quantities of highly indebted countries to bring their interest down. The ECB intervention on the secondary market may cut borrowing costs for some EU member countries. In the short run, the euro area needs ECB bailout program to protect member countries from contagion and monetary policy to promote growth. Without at least partial mutualisation of partner debt by the ECB buying bonds of high indebted countries or/and larger funds accumulated in the EU budget, potentially fundamentally solvent countries might be forced into bankruptcy. An example of positive intervention on the secondary market is the ECB decision in August 2011 to buy Italian and Spanish bonds. The Italian debt was huge, assessed at 1.8 trillion euro, and the ECB 2 billion euro intervention had mainly psychological effect. This intervention decreased the prices of Spanish and Italian 10 year bonds on the financial market from more than $6.1 \%$ to $5.3 \%$ in Italy and from $6.0 \%$ to $5.2 \%$ in Spain. However, to cure internal disequilibrium in the euro area, only structural reforms in partner countries, as well as the institu- 
tional reforms in the EU, the ECB intervention would solve single currency long term illness.

\section{Coordination of Fiscal and Monetary Policy}

The euro crisis that started in 2008 has clearly shown that more attention has to be paid to common governance in EMU, because economic coordination between partners has not been strong enough to prevent macroeconomic and fiscal imbalances within the euro area. Need for a coordination of budgetary policy in EMU arises from growing economic integration and likely spillover effects, when budgetary policies in one member states may have impact on the economies of other partner countries. Fiscal discipline and more belttightening - in the opinion of Wyplosz - increases the likelihood that the EU as a result of the euro crisis could face lost decade in 2010-2020 like Japan experienced in the 1990 (International Herald Tribune 2012). Therefore, the countries with negative balance and high public debt should adjust as well as countries with external surplus and budgetary equilibrium. In the economic crisis some countries - members of the single market must assume the role of engine of economic growth. The decrease of demand in one group of partners may be compensated for by the public spending in the other countries. The partners that assume the role of 'engine of economic growth' may be the countries in which public finances are in equilibrium or close to equilibrium. More public spending in one or a few countries may have positive impact by growth of import from partners carrying out the policy of stabilization their public finances. There would be no inflation pressure, if policies were rightly coordinated among partners and with monetary policy provided by the ECB.

Generally normative theory stresses the 'shock absorber' role of budget deficit and prescribes that government debt should be adjusted over time to respond to exogenous shocks. However, political scientists outline several reasons why the political system could affect national debt decisions. The weight that the government attaches to the future is affected by two features of the political system: its instability and its polarization. In the transformation countries, more unstable and polarized systems behave more myopically. Disagreement among different decisions makers result in the postponement of unpopular policies and accumulation of public debt. The less likely a government is to be reappointed, the higher amount borrowed is. A weak government unable to cut expenditures or raise taxes treats public debt as a residual source of finance. Hence debt reduction is not only an 
economic decision, but is intrinsically related to the working of the political system.

On the one hand, governments finance budget deficits by increasing public debt, on the other hand, they collect taxes to pay interest to bondholders. When governments collect taxes to pay interest payments, an excess burden is created. The need to make the interest payment on a large debt may also contribute to growth of inflation. Since the EMU removes the possibility of adjusting the nominal exchange rate, the rise in interest rates can no longer be limited to the country running a budget deficit. If governments sell new bonds to pay off the holders of the old bonds the question arises whether, it is possible for governments to fail to make payments back and, like a business corporation, to go bankrupt. It is frequently stated that a government cannot go bankrupt because it has the competency to levy taxes in whatever amounts are necessary to service the debt. Furthermore, governments have also the power to print money at least indirectly pressing central bank to create additional money to avoid default. Growing inflation may decrease the value of circulating public debts. However, in the euro system, the governments of member states have lost their any influences on the ECB decision to supply money. The central banks cannot also decrease the value of debts by growth of domestic inflation, as that is limited by the ECB goal of price stability and taken into consideration throughout the euro area. Partner countries have become aware that the bail-out option of exchange rate devaluation no longer exists The extent means with which debt can be reduced rest entirely on budget policy. Hence, it seems that for these reasons the probability of default for a highly indebted country is higher among member states than outside the euro area.

The theory of fiscal federalism points out that fiscal responsibility can be divided between the UE and the member states in the same way as they are divided between national states and their regions. There are two main economic arguments speaking for fiscal federalism:

- spillover effects (negative externalities) if actions undertaken in one country lead to inefficient outcomes in the partner country;

- increasing returns to scale when, for example, an anty-cyclical policy is more efficient when carried out on large scale.

The common exchange rate policy must be a part of this mix, as well as the surveillance of macroeconomic imbalances, and including competitiveness divergences. There are also two main arguments for retaining fiscal sovereignty with monetary union' partner countries: heterogeneity of preferences and information asymmetries. These arguments indicate that national or regional governments are the best suited to shape fiscal policy to regional preferences (Baldwin, Wyplosz 2006, pp. 410-411, European Commission 2011, pp. 68-69). So far the EU initiative to improve economic governance 
seems to be moderate and perhaps too late steps towards effective coordination. The EU propositions take into account the second group of arguments to avoid and correct budgets deficit and public debts in fiscal policies in member states. Governments also put stress on political control of EU institutions over deficit and debt development to be more strict and automatic. The fear of the loss of sovereignty with regard to this state of affairs comes from mingling two crucial aspects of fiscal policy: structural and stabilization. Structural tax policy is mainly microeconomic and can be decided upon at the national level. However, the income stabilization policy can be accomplished effectively at the supranational level.

Overall, in the euro area, macroeconomic stability is provided by national budgetary policies, which perform a function as shock absorbers in any single country. There are valid arguments for jointly imposing discipline and budgetary stabilization coordination, as well as optimal budgetary spending in the whole area in the time of crisis. In 2010-2013 most the EU members faced the problems of excessive public debts and had to increase taxes to speed up fiscal consolidation. Tax consolidation is an important means to recover budgetary and external trade equilibrium among partners in the euro area. However, in the fully liberalized European capital market, the excessive growth of taxes in one country may have negative externalities due to costs of capital outflow. A decrease of a tax base in one country, which reduces the supply of that country's public goods, may be correlated with an increase of the tax base in partners countries. Simulation conducted by the Institute for Prospective Technological Studies shows that the loss of efficiency due to tax increase would be reduced if the tax rises in the EU countries were to be coordinated in order to 'internalize trade - related spillover effects'. So fiscal consolidation in the EU should be arranged in a coordinated manner, as well as, increases of taxes and the types of taxes included (better indirect taxes than direct taxes). The result of the analysis indicated that efficiency gains would be potentially higher for VAT than labor taxes (SaintEtienne 2011, pp. 121-122).

In the euro area no bail out clause implicitly assumes that a member country could become insolvent. In the US the default of a state is possible whenever lower level governments are in financial trouble. Nevertheless the US federal system can print dollar to cover debt, but in the euro area the ECB cannot. Several European governments have put pressure on the ECB to greatly increase its purchases of sovereign bonds, which they regard as a possible solution to the debt crisis. It seems that in time of crisis the ECB may assume a more active role to contain the euro area debt crisis, and under the conditions to undertake the necessary reforms in highly indebted countries. Loosening of the ECB policy is connected also with weakening of the euro, as it dropped to low level of about 1.2 US\$ per euro at the beginning 
of 2012. An economic rule of thumb explained that a $10 \%$ fall in the euro may boost export and economic growth of about $1 \%$ after six months, especially in export countries that are the most sensitive to euro exchange rate. Moreover, all member countries may accept a modestly higher overall inflation than the Maastricht price stability goal allows, rather than fall into a possible deflationary spiral. Temporary money creation would not be inflationary in a depressed economy, and it would help to avoid high employment and reduce public debt in some euro area countries. It seems that the task of the ECB should be enlarged beyond only the keeping of an inflation down. The ECB should be also responsible for financial stability and growth: if financial stability is paralyzed then the growth does not come, so a better way to growth is through 'quantitative easing' that will recover financial stability. After ten years of restrictive monetary policy, it seems that the temporary ECB intervention would not destroy its reputation.

However, the ECB cannot substitute for fiscal policy coordination in the euro area. Against the ECB indirect 'hidden' fiscal transfer, there are propositions concerning the introduction of a eurobond to be issued by a single euro area authority (EBC or by European Investment Bank). Eurobonds placed on the market by the EU institutions are to convert a share of national members countries debt to the Community. The eurobonds may be also guaranteed by intergovernmental agreement, as such they would gain more trust than bonds issued by the governments of the member states. The bonds could be bought by foreign investors and many of them are in favour of investing in eurobonds against national bonds. Jean-Cluade Junncker - president of the Euro group and Giulio Tremonti - Italian ministry of finance - proposed to issue euro bonds represented up to certain limit : to $40 \%$ of the GDP of the EU for maintaining not only the budgetary solidarity of member states, but also serving of default and bailing out of the bonds of the member states (Towards a Genuine..., pp. 3-715). There are also propositions to establish a system of common issuance of bonds in a progressive and partial way up to a maximum of $60 \%$ of GDP. A conversion of debt up to $60 \%$ of the GDP from member countries to the EU would mean that their remaining debt would be Maastricht compliant. The creation of eurobonds may bring the lower interest rates and attract foreign capital to invest in their emission, for example, from China. It may mutualise debt in the euro area and reduce the borrowing costs of such countries as Spain or Italy. However, issuing jointly backed euroobligations will not make sense until the euro area reaches some kind of fiscal union. The eurobonds will functions correctly only if they possess sufficient sovereign economic policy power to ensure their credibility. The benefits of a euroobligation relative to no bail out actions are generally considered to be greater financial stability. The German opposed the eurobonds initiative, because of fears that weaker countries could 
get a free-ride on the stronger credit ratings of stronger partners. Eurobonds may have higher rates than German bonds but lower than in the other countries. Germany was afraid of a growth of interest rates and raised expectations among market participants that eurobonds would become the norm and a factor that could actually promote future crises. Overall opponents of eurobonds underline the possibility of mutualisation of some losses, excessive emissions and higher inflation on the single market. Nevertheless, the euro area countries have not yet set out a road map towards eurobonds and the partners countries are rather in favour of setting up euro area common bail-out funds that would be able to buy sovereign bonds.

Moreover, the euro area needs a banking union with common banking supervision. The European banking union is proposed, with common capital requirements and supervision and deposit guarantee system (DGS) with a goal to compensate bank deposit holders for failures of an individual bank. Integrated supervision of banks in the euro area is necessary to ensure the application of common prudential rules. Such supervision may reduce the probability of banks failure and prevent the spreading of crisis throughout the whole EU. The banking union should also minimise the cost of possible bank failures and financial intervention to citizens of member states. The current architecture of European regulations provided incentives to buy governments debt consider as 'free of risk'. For example, European banks were not obliged to set aside additional reserves when they bought governments debt. Hence new rules have been proposed (Basel III banking rules) that would be introduced in 2018 to hold capital reserves to at least $3 \%$ of all their holding. Parallel to this process is the creation of a common fund to bail out failing banks and guarantee deposit over the euro area. The credibility of any deposit guarantee requires of course access to a solid financial backstop. A European deposit insurance scheme could introduce the international dimension to national deposit guarantee schemes for banks overseen by the European supervision. So called banking union is a part of proposed new economic governance of the euro area able to carry out a proper financial policy for all member states.

Van Rompuy's report in June 2012 mentioned four essential building blocks of a genuine economic and monetary union that will have to be put in place next. In the view of the report, they offer a coherent architecture for long-term stability and prosperity of EMU and include:

- An integrated financial mechanism with a view to ensure financial stability, common supervision of banking at the European level, resolve banks failures and guarantee customer deposit,

- An integrated budgetary framework to ensure sound fiscal policy making in euro area. Such framework encompassing coordination, joint decision-making, different forms of fiscal solidarity, commensurate steps 
towards common debt issuance;

- An integrated economic policy coordination at national and European level to promote sustainable economic growth;

- Democratic legitimacy and accountability of decision- making within the EMU (Towards a Genuine..., pp. 3-715).

The common monetary policy must be joined more closely with harmonized tax policies in the member states. Public spending coordination cannot be concentrated only on one country's market and political cycle, but must take into consideration the spillover effect on the partner countries. The Maastricht criteria should govern without exception among the states and public finances should be considered jointly when the deficit in one country may be "equilibrated" by the surplus in partner country. Fiscal policy coordination is needed to discourage free riding and to induce governments to internalize the negative externalities. Uncoordinated fiscal policies might drive up interest rates over the entire EU, depressing capital formation, growing national debt and hampering Europe's international competitiveness (The Euro Crisis... 2011, UBS Quantifies... 2011). In the future it is only under conditions of strict common fiscal policy that it would be possible to enable the common borrowing for eurobonds. Common emission of eurobonds in the framework of the EU budget, equipped with more resources and more harmonized taxes, might avoid the problems of financing of public debt and spreading in interest among members states. Like in the European Monetary System, one can also envisage setting up a European Monetary Fund that is able to bail out national's debts and transfer stabilization aids from richer European countries to the euro-zone periphery.

\section{The Future Evolution of Euro Area}

The worst outcome for the highly indebted euro area member countries would be to leave the euro area to accomplish devaluation of their national currencies. The decision to leave by one, a few many or even all the countries of the euro area should be based on the profits and costs analysis regarding the economic effects imposed on his economy and the whole European Single Market. A country can withdraw from the EMU in order to be free to resort to debt monetization. To the extent that debt would be denominated at home currency (instead of euro), this could alleviate a country's public finances. However, coming back to the home currency may be connected not only with administrative costs of money exchange, but also higher inflation, collapse of financial sector, a loss of credibility, and corporate defaults and separation for years from the capital market. Negative effects would be felt in the euro area as well in the form of higher inflation and 
a drop of trade and investment. Sometimes the example of Argentine has been evoked, as Argentina fell into financial crisis in 1990 having fixed exchange rate of its peso to the value of the US dollar. Argentine entered a spiral of external trade and budget deficit until it devaluated the peso and restructured its public debt. After devaluation and debt relief Argentine returned to the path of economic growth. However, a return to a free exchange rate by the members of the euro area would be costly to the whole single market. In total, all the partners may lose: a devaluation of currencies of the weaker members might accompany an appreciation of the currencies of stronger partners (Germany, Austria, and Holland, Finland). After that, the regional policy may be reformed and diminished, as well as the common agricultural policy. Protection tendencies could arise and the Schengen agreement could be dissolved. So, a country that is considering exiting the euro area should take into consideration that there may be little prospect that devaluation offers much and that structural reforms may count for much more.

One can hardly imagine that the members of the current euro area would accept as a solution such as a leap backwards into completely freely exchange rates. The cost of reintroducing a national currency seems to be much greater than leaving only a fixed exchange rate, like Argentina did. The introductory calculation estimated a decrease of at least 10\% of GDP of the euro area in the case of dissolvent. Daniel Gross shared the opinion that while Greece might ultimately require financial aids of about 400 billion euro, allowing Greece to abandon euro would cut its nominal GDP by at least half, making debt equivalent to $400 \%$ of GDP (The Euro Crisis...2011). A breakup of the euro area may turn out to be too costly in comparison with deeper integration and fiscal union. The cost of breaking up with the euro may be especially important for small open economies, because for these members internal reforms are better alternative. According to the UBS assessment, each Germany citizens will have to pay at least 1000 Euro to bail out Greece, Ireland and Portugal's debts, hence the cost of an eventual bail out seems to be lower, than the cost of a possible break up of the euro area (UBS Quantifies... 2011). For example, Slovakia's exportoriented economy has recovered quickly from the financial crisis. After two years of budget deficit at nearly $8 \%$ of GDP, the government cut spending and raised taxes to the level of $2.5 \%$ of GDP. Belgium is another example of a country that has successfully reduced its public debt. Once the most indebted country in the EU (with a ratio of debt at $134 \%$ to GDP in 1993), Belgium steadily reduced its debt to $84 \%$ by 2007 . Thus, default is unnecessary, if sensible reforms are introduced. 
The present crisis of the euro area shows that euro as a currency seems to be more an element of the economic union than an element of the European Single Market. The single market may function with euro and without the euro, and the benefits deriving from one money for one the market are rather modest. In practice, the size of the cost of exchange rate instability suggest that it is an obstacle to trade development. By and large, traders seem to be able to hedge against the risks of exchange fluctuation. National currencies are in the same way restrictive to foreign direct investments. However, when foreign investments are treated as alternatives to exports, some investments may be encouraged by the existence of currency risks. According to the theory of optimal currency area, the economic benefits from one money for the single market are conditioned by several assumptions. In asymmetric shocks, members countries have two safety valves at their disposal: elastic labor marker or fiscal policy. Because the labor market in the EU is two times less elastic than that in the US, in the euro area the burden of fighting against the crisis falls on the fiscal policies in the member states. A common fiscal policy in the euro area may take the form of supranational fiscal policies with a centralized budget or some part of it, or through coordination of fiscal policies in member states. A centralized budget would be able to accomplish fiscal transfers from more to less prosperous region and - in the opinion of P. Mortimer-Lee - without them the prospects for EMU are rather gloomy (Mortimer-Lee 2001, pp. 65-67). Coordinated adaption of common regulations and harmonization of national laws and rules, may also lead to convergence of the target variables of policy (Molle 1990, p. 14). The frontier of the EMU should be limited by the possibility of conducting the effective coordination of fiscal and monetary policy between member's countries.

Therefore, political factors of monetary union seem to be at as important as economic factors. Some authors asserted even that the raison d'etre of monetary union was political rather than economics and the success of monetary integration rests on political union, and not on economic theories (Chang 2009, pp. 253-261). The euro was introduced not only to enlarge economic profits from the single market, and also to speed up European integration towards economic union. Before the establishment of the euro area $\mathrm{H}$. Tietmyer, president of the Bundesbank, argued that after certain point economic integration cannot realistically be expected to advance without the prospects of progress in the field of politics (Tietmeyer 1995). The transfer of an elementary sovereign right, such as monetary policy, to the ECB is likely mark that point. O. Issing shared the view that if it is to be workable at all, monetary union requires a full political union (Issing 1996, p. 14). M. Wolf predicted in 1996 that under the EMU there would be incentives for individual governments to pursue deficit financing with the expectation that they would be bailed out by the ECB. The greatest risk is that 
those countries with initially high levels of public indebtedness might find the effort of lowering public debt excessively painful. This risk would be reflected in high euro interest rate (Wolf et al. 1997, p. 6). The latest financial crises have also convinced the European politicians to attempt a closer political union. During a meeting in Strasbourg in November 2011 even German chancellor A. Merkel fixed on the long term goal of fiscal union. Merkel underlined that changes to the European Treaties are the only way to restore confidence in the financial markets (Financial Times 2011, p. 4). Some politicians are aware that a monetary union requires the relinquishment of much of the budgetary sovereignty held by member states.

Although the stable currency and low interest rates have been helpful to the European Single Market, more needs to be done to ensure better governance in the euro area to improve budgetary coordination or even partial budgetary unification. The common monetary policy seems to be more an element of economic union than a single market and that the latest crises have showed that in the further transfers of national policy sovereignty from the member states to supranational organs is necessary so that the monetary as fiscal policies may be better coordinated, as must be a proper functioning of a currency union. The key reason why a single currency works in the US and does not work so efficiently in the EU is the insulation provided by the federal fiscal system. Managing a large monetary union should be straightforward like in the Federal State. Monetary policy requires the Central Bank to take monetary decisions in the name of all members countries as well as manage the substantial union wide budget to transfer income from more successful parts to the less successful countries and regions. Government borrowing should operate through a single union wide bond market with borrowing determined by a decisive central authority. In the US, Federal Reserve manages the union's monetary policy via a single bond market, with borrowing belonging to the institutions of the federal states, while the borrowing of states and municipalities is constrained due to their inability to monetize their debt. After the War of Independence, the USA confronted the same problems with the debts incurred by the states as euro area did and had resolved it by assuming these debts issuing new federal debts. Because of the need to bailout debt in some countries, central control over budget deficit seems to be necessary. The EU moved towards the EMU without giving it the ability to bail out public debts of partner countries and make transfers between them because of the limited size of its budget. Therefore, in the period of economic crisis a new fiscal pact for economic convergence in the EU is needed and it must complement the current plans of austerity measures. Cohesion policy and structural funds that concentrate their activities on income convergence between partners and their regions, should reorient their policy also to include the stabilization goals. The European Invest- 
ment Bank may deploy funds to match investments in countries undergoing structural reforms. Furthermore, the ECB should be more proactive in buying the public debts of partner countries. The ECB can assist the banking sector in reforming countries and operates on the market to bail out countries debt. In the view of such grow of debt and the rise of interest rates in some euro area countries, the question arises whether part of the countries will be able to pay back their debts and manage to deliver on both fiscal disciplines and economic recovery. To put it another way, will Germany and other northern members of the UE aid southern countries by bail out and reschedule their debts and by offering them palliatives such as reduced interest rates for emergency loans. The financial crises in 2008-2013 showed that the euro area institutional system is inherently fragile. Due to the economic and financial interlink among the member countries the fragility of one or a few is becoming fragility of all the partners. In connection with the debt crises which were particularly severe in southern partners and their negative consequences in the entire EU, the question arises what would the future of the euro area be. One can imagine three scenarios:

The first is to rely on euro area partners countries individually making reforms. Some economists and politicians assume the EU needs country by country fiscal reforms and not a renewed push for further fiscal union and political integration. All initiatives should be designed to enforce the Maastricht criteria. They should set on fiscal discipline, the avoidance of moral hazard and preserving the ECB's independence at any costs. The governments of the partner countries would not stand behind financial system and fiscal policy discipline. They underlined that neither fiscal integration in the EU enforcement of common budget are possible. During economic crisis the countries would be allowed to fight against it freely with their own fiscal policy means. Moreover, essential element of structural changes are to be reforms of the labor market with a view to increase its elasticity. The example of Germany is often quoted, where labor market reform has cut unemployment from 5 million to 3 million and increased the competitiveness of export. An example of this in practice is also successful reforming of the Baltic States. Before the financial crisis in 2008-2010 Lithuania, Latvia and Estonia had high external and internal imbalances due to the higher imports than exports, capital inflow and negative real interest rates (inflation was higher than theirs long term interest rate), and a bubble was created on the real estate markets. Against a low level of initial debt, the Baltic States decided to adjust to large internal and current account deficit by the supply side economy. The activities of the programs were concentrated on cuts in budgetary spending, hampering domestic demand, a rise in real rate of interest and adjustment to prices, of employment and wages. Their deflation policy turned these three countries into deep recession and caused a drop of produc- 
tion by $-14.7 \%$ in Lithuania, $-18 \%$ in Latvia and $-13.9 \%$ in Estonia in 2009 . The prices of apartments and houses fell by $50 \%$ and wages in Lithuania fell by $10 \%$ in 2009 . By refusing to devaluate their currencies recovery after two years, Estonia GDP grew by $8.4 \%$ in the second quarter 2011 while Latvia had a $5.7 \%$ growth and Lithuania had a $5.9 \%$ growth. Internal adjustment of production, prices, and wages, tightening of public finances, and temporary growth of unemployment acted like as devaluation and helped to restore internal and external equilibrium. However, the level of indebtness and its service in Greece, Italy and Portugal is much higher than in the Baltic states. If other larger euro area members were to follow the Baltic States' policy, there would be a risk of a recession throughout the whole EU. If many euro member countries could not pay back their debts, their lenders can expect to lose big parts of what is owed to them, thereby increasing the danger that nations will leave the euro area. Some economists are in favour of allowing the highly indebted countries to go bankrupt, so that they could start new independent policies for their economies. If in the EU the highly indebted nations were allowed not to pay back their national debt and to default, then the financial markets would be overwhelmed by the many possibilities in the bankruptcy of banking sector. This could lead other member states to exit, triggering a domino effect. No institutional reforms in the EU means acceptance of the inherent fragility and potentially break up of euro area.

The second scenario is to limit the euro area to the optimal currency area. The member countries of the optimal currency area would be so similar to one another that large divergences would be unlikely. The countries included in this "new euro area " should be characterized by high mobility of labor force, strictly integrated capital market, and high proportion of tradable to non-tradable goods, high level of GDP and similar diversified of their economies. Additionally, theorists of integration limit also such area by the possibility of conducting the effective fiscal and monetary policy. That means that the euro area would be limited to the so called core countries (France, Germany, Austria, Finland, Benelux countries), if these countries were able to create economic institutions to manage coherent monetary and fiscal policy. It is the scenario to divide of the EU in two speeds Europe (an idea that Poland oppose). One group of countries would go into a federal Europe with harmonized economic policy, more solidarity and regulations (particularly in financial services and the capital market) and the second group that follows only the rules of the single market. The peripheral countries (those presently with severe debt problems) would be excluded at least temporarily from the euro area. They would be allowed to come back to the euro area after they had accomplished of several strict conditions. But moving in this direction would engender transitional shock from a partial breakup. The partners of the centre may suffer as well from the partial break up due to temporary 
instability on the financial markets. In the long run, they would probably face appreciation of euro in reference with dollar and other currencies.

The third option is to move toward closer political union as an effect of the recent economic crises. The financial crises have exposed the weakness of the Maastricht Treaty and further integration seems to be the solution to the current crisis in the euro area. The crises revealed that monetary integration has crossed the Rubicon towards a more harmonized economic policy. Monetary integration simply does not work without further tax integration policies among member states. The countries of the euro area fell into debt crises relatively easily despite Maastricht conversions criteria and Stability Pact. To make the convergence criteria more obligatory, partner countries have agreed to introduce more strict debt and deficit rules to be included in the law of member states, but there is no guarantee that debt crises will not happen again. To escape from the current crisis and prevent the future one, there is no alternative but to elaborate a proper policy mix between monetary policy and fiscal policy. Now, in the euro area there is a combination of decentralized national fiscal policy with rather strict monetary policy. Budgetary policy in the euro area works primarily as an absorption function at the national level, and less at establishing of an optimal budgetary spending for entire EMU. The reforms should institute more strict and coordinated fiscal policy and more proper monetary policy, taking into consideration financial stability and economic growth. It is not a question of introducing one or other new instruments, because one instrument can be substituted by another. Rather, this is a new viable institutional arrangement empowered to carry out rational economic policy. A monetary union should lead to a fiscal union and a fiscal union to a banking union with deposit insurance in the EU. A banking union in the euro area would probably be unworkable unless accompanied by a full fiscal union. Some economists thinks that the euro can be saved only by stronger economic union among member states. The European Commission even indicate the necessity to establish of some kind of common economic government able to take up economic decisions and formulate common economic policy. The EU must put in place some form of economic government that is able to coordinate fiscal policies with monetary policy of the ECB. The best chances for economic recovery involves governments working together to increase demand and to augment business confidence. No institutional reforms in the euro area means acceptance of internal fragility. Of course, government debt and the potential for default cannot be linked only to the euro and functions of the ECB . In a federal state like the US nobody linked the potential default of one state to the dollar functioning as a legal tender. For example, during a recent budgetary crisis the State of Illinois simply stopped paying 5 billion of its bills, and California issued vouchers for wage payments. In both states there were cuts in 
public services. However, nobody envisaged a bail out financed solely by other US states nor an exit from the monetary union. An analysis of the institutional manner in which the US deals with the crisis reveals federal country wide prudential rules for banks and Federal Reserve System as a lender of last resort (Beblavy et al. 2011, pp. 341-343). The central budget in the USA also helps states by automatic stabilizers when economic crisis begin. Moreover, in the US there is a dialogue between the Federal Reserve and President of the US, such a dialogue does not exist in the euro area neither between the ECB and the European Commission nor between the ECB and governments of members states (Allegre 2011, p. 153).

Thus far we do not know precisely what the economic benefits and costs of closer economic union and coordinated economic policies are. Coordination commits partners to agreement on the actions needed to accomplish a coherent policy for the euro area. Because banking sector bears the huge costs of the euro crisis first of all there is a need of coordination program in banking to recapitalise some banks in different partners to make them solvent. European banking union is proposed with common capital requirements and supervision and deposit guarantee system (DGS) with a goal to compensate bank deposit holders for failures of individual bank. Governments could also do much to coordinate economic policies so as to better align spending and taxing. These coordination can help to avoid contradictory means and negative externalities, and to provide proper income stabilization policy for all euro area. In order to coordinate effectively the fiscal policies among members states, credible text plans for budgetary projects should be drawn and based on independent growth forecasts and checked by" independent budgetary council". To this goal, it is necessary to normalize and harmonise presentation methods concerning national budget that partners budget can be aggregated to establish a consolidated euro area budget (local and social finances included). The coordination should be served by Eurostat as an independent European statistics agency, a combined network of National Statistics Agencies (Arthuis 2012, pp. 2-8). Fiscal coordination (or putting it in the far reaching goal fiscal federalism), does not necessarily mean total unification of all national budgets into one supranational budget. It may be linked with some further harmonization of taxes, like direct taxes for enterprises at a minimum level of $18-20 \%$. Accumulation of more common financial resources may be linked to the EU budget, or more resources may be transferred to the European Financial Stability Facility (later to European Stability Mechanism). Without at least partly mutualisation of partner debt and a larger bailout funds (for example in the form of European Redemption Fund) fundamentally solvent countries might be forced into financial crisis on an occasion of economic downturn. According to Ch. SaintEtiene the enlarged EU budget able assume new functions might be com- 
posed from one third of taxes levied on firms, $0.5 \%$ from the value added tax, $1 \%$ on all revenue and $2 \%$ on all consumption spending in the euro are. The enlarged EU budget or stability mechanism would then be able to absorb effectively asymmetric shocks in the euro area before they affected all partner countries. It can help with adjustment problems in the monetary union, if the common budget is equipped with common resources so that should an occasion arise and funds must be transferred, the transfer can be organized. Moreover, coordinated fiscal policy might include not only some fiscal standards, but also common rules concerning spending on the occasion of an economic downturn. Coordinated budgetary spending should serve first and foremost the strategic growth policy of the members states and support mainly: research and development, creation of the new technology and products, energy policy, and development of infrastructure, finance a European Venture Capital Fund for small and medium firms etc. (Saint-Etienne 2011, pp. 108-125). In order to finance such growth under the European economic recovery programme and to stabilize euro area debt, the EU may issue also its own bonds up to $60 \%$ of partner's GDP, rather than only national bonds denominated in euro. The euro bonds proposition seems to be a complementary initiative to policy coordination, as they can bring the best effects in the framework of fiscal union. President of ECB Dragi told that Euro bonds make sense when we have a fiscal union, otherwise they don't make sense. European Council President Herman Van Rompuy stated also that Eurobond could be considered only after a new stage in the EU's fiscal and economic integration (BaronCrespo, Holland 2012, pp. 2-8, 28-29).

In the short run, the euro area needs more investments, slower fiscal adjustment, looser monetary policy to promote growth and a more financial support to protect member countries from contagion. In the long one, the euro area needs structural and institutional reforms. For the future development of Europe, Agenda 2012 calls for greater cooperation between the EU partners regarding the quality of public spending and to get this positive synergies the euro area finances ministers will have to turn budgets around to stimulate spending and potential growth. The propositions of reforms are connected directly or indirectly with these fundamental questions: if the euro area should be less integrated or more integrated among members; if partners countries fight the crisis on their own or in close cooperation with other countries, if the solution for the euro area is to introduce new mechanism of integration to go into proper mix between fiscal and monetary policy or to encourage the most indebted members to exit the euro area; if the final model of integration to be achieve is a federalist structure of governance in the EU like in some federal states. All proposed steps against euro crisis are mutually collarated: monetary integration requires striker fiscal integration, fiscal integration requires banking union but banking union is going to re- 
quire some form of a political union. This way, the debt crisis in the euro area may present an opportunity to renew the strength of European institutions. It was often repeated during previous crises in the EU that integration process in Europe cannot be stopped. It is like a snowball at the top of a large hill or like riding the bicycle which we must always pedal, new crises leading to new solutions and more intensive integration among members states. It seems that it is in the vital interest of Poland to join only a strong euro area with good governance and a fully fledged mechanism managing it, which is able to effectively carry out monetary, as well as fiscal, policy and more automatically overcome unequlibrium and eventual financial and economic shocks. Otherwise, the attractiveness of monetary union beyond the European Single Market (which brought Poland the most integration profits) seems to be limited.

\section{References}

Allegre C. (2011), Peut-on Encore Sauverl'Europe, Plon.

Arthuis J. (2012), Future of the Eurozone: proposals for political integration, "European issues", Foundation Robert Schuman, No. 232.

Baldwin R., Wyplosz Ch. (2006), The Economics of European Integration, London. BaronCrespo E., Holland S. (2012), Resolving the Eurozone Crisis and Enhancing Global Governance, unpublished Brussels appeal, February.

Beblavy M., Cobhan D., L'udovit Odor (2011), The Euro Area and the financial crisis, Cambridge.

Chang M. (2009), Monetary integration in the European Union, London.

De Grauwe P. (1997), The Economics of Monetary Integration, Oxford.

European Commission (1990), One market, one money, European Economy, No. 44.

European Economy News (2010), No. 19 October.

European Union Public Finance (2008), 4th Edition, Luxemburg.

Financial Times (2011), Friday 25 November.

Financial Times (2012), Wednesday January.

International Herald Tribune (2012), Monday January.

Issing O. (1996), Europe: Political Union through Common Money?, Occasional Paper 98, London.

Kundera J. (2004), Jednolity Rynek Europejski, Kraków.

Le Figaro (2011), Un pland a triple détente pour calmer les marches, vendredi 22 juillet.

Molle W. (1990), The Economics of European Integration. Theory, Practice, Policy, Dartmoutg.

Mortimer-Lee P. (2001), Czy Euroland może funkcjonować przy jednej stopie procentowej [in:] P. Temperton (red.), Euro. Wspolna waluta, Warszawa. 
New York Times (2012), The Global Edition of New York Times, Monday, January 2.

Saint-Etienne Ch. (2011), La fin de l'Euro, Paris.

The Euro Crisis: How Much worse can it get, http://www.time/world/article/08599 .2083021,00.html).

The Impact of the Euro. Debating Britain's Future (2000), M. Baimbridge, B. Burkitt, P. Whyman (ed.), London.

Tietmeyer H. (1995), Waehrunspolitische Kooperationzwischen Zentrabanken, Deutsche Bundesbank Auszugeaus Presseartikeln, 18 April.

Towards a Genuine Economic and Monetery Union (2012), Report by President of the European Council. Herman Van Rompuy, EUCO 120/12.

UBS Quantifies Costs of Euro Break Up, http://blogs.wsj.com/economics/2011/ 09/07.

Wolf M., Scharer H., Johnson Ch. (1997), The Politics and Economics of a Single Currency, London.

Yvars B. (1997), Economieeuropeenne, Paris. 
